\title{
Meteorology and Metrology: Evaluating Parallels in the Ethiopic Parables of Enoch and 2 (Slavonic) Enoch.
}

\begin{abstract}
:
This article will examine a set of distinctive conceptual and terminological combinations in the Ethiopic Parables of Enoch and the Slavonic 2 Enoch, associated with the meteorological elements and their angelic custodians/managers. These texts contain extended accounts of the storehouses (or treasuries) within which the elements are stored, and they exhibit a particular interest in how their angelic custodians distribute the elements to the earth; the imagery of distribution is, in turn, connected to metrological concepts informed by the imagery of a righteous balance (or scales). We will consider how other texts offer limited parallels to these combinations, a comparison that will help to illustrate the particularly close connection between the Parables of Enoch and 2 Enoch. The closest parallels are found in 3 Enoch, though here we will also see some striking developments that suggest the Ethiopic and Slavonic works preserve traditions from an earlier point of evolution. Some suggestive parallels will also be noted in works of Syrian origin, which might cast new light on the provenance or transmissional pathways of the Parables of Enoch and 2 Enoch.
\end{abstract}

\section{Introduction}

This article will examine a dense set of correspondences in the meteorological and metrological language of the Parables of Enoch and 2 Enoch, considered in relation to a range of other texts that use similar language. By evaluating the degrees of similarity and difference, and mapping our findings according to the likely origin of these texts, we may find some new data relevant to the notorious problems of provenance and transmission that attend both texts.

Specifically, within this article, we will consider the descriptions of "storehouses" or "treasuries," in which are contained various meteorological elements, and of a "righteous balance/scale" that is associated with both meteorological order and divine judgement. While 
the terminology itself is not confined to these texts, and has some biblical backgrounds that must be considered, the distinctive combinations in which it is found here suggest a particularly close relationship between the traditions found in The Parables of Enoch and 2 Enoch. A comparison with the use of similar language in other ancient texts will highlight points of overlap, some of which show some interesting geographical clustering, but it will also throw into sharper relief the particular degree of similarity between these two texts, especially when considered in relation to the other tractates that comprise 1 Enoch. Given that the two texts have been preserved in very different linguistic contexts-Ethiopic and Slavonic - this invites the question of how their relationship is to be explained, and whether a common provenance or transmissional context in their history might make sense of the evidence.

In what follows, then, we will begin by documenting the use of this language and imagery in the Parables of Enoch and 2 Enoch, evaluating these in relation to the primary Enochic literature, and particularly the Astronomical Book. This will constitute the largest section within the study. We will then examine the biblical material that provides at least part of the background to the language and imagery before turning to some partial parallels in the Dead Sea Scrolls. After a brief consideration of a significant parallel in the rabbinic tractate b.Hagigah 12b, we will consider some quite striking correspondences in the Hebrew Book of Enoch, which we today commonly designate as 3 Enoch. We will then consider a number of parallels in several other pseudepigraphical works, which will raise an interesting question about either a provenance or a stage of transmission in Syria. Finally, by way of conclusion, we will offer a synthetic reflection on the evidence.

\section{Storehouses, Treasuries and Measures: Documenting Parallels in The Parables of Enoch and 2 Enoch}

Meteorological and cosmological language is found at several key points in the text of the Parables of Enoch, with notably dense accounts in the first and third parables, located in chapters 41/43 and 60/69 respectively. In 2 Enoch, the material is distributed more widely, though with a number of particularly dense clusters built into the structure of the book; the meteorological imagery that we will consider here is located in 2 Enoch 5-6 and 40, and the cosmological or astronomical material is found in 11-16, 30 and 48 . Because the material in 
the Parables is more tightly located, we will allow it to anchor our study, with the material from 2 Enoch discussed and tabulated in relation to it. For the sake of focus, our study will also principally focus on the material found in the first Parable, as it is found in chapters 41 and 43, with the material from the third Parable discussed in comparison to this. The material in these two chapters is conceptually unified; it may, in fact, originally have been a single account within the text, a different arrangement than is currently reflected in the manuscripts, where the unity and flow of chapters 41 and 43 is fractured somewhat by the text of chapter 42. ${ }^{1}$ The table below uses the standard recent translations, but we will offer some comments on both in the discussion that follows.

\begin{tabular}{|c|c|}
\hline Par: & Enoch (Longer Recension) \\
\hline $\begin{array}{l}41: 3 \text { And there my eyes saw the secrets } \\
\text { of the lightnings and the thunder, and the } \\
\text { secrets of the winds, how they are divided to } \\
\text { blow upon the earth, and the secrets of the } \\
\text { clouds and the dew. And there I saw whence } \\
\text { they proceed in that place, and from there } \\
\text { they saturate the dust of the earth. } \\
{ }^{4} \text { There I saw closed storehouses, and from } \\
\text { them the winds are distributed; the } \\
\text { storehouse of the hail and the winds, the } \\
\text { storehouse of the mist and of the clouds, and } \\
\text { its cloud abides over the earth since the } \\
\text { beginning of the age. }{ }^{2}\end{array}$ & $\begin{array}{l}5: 1 \text { And there I perceived the treasuries of } \\
\text { the snow and ice (or "frost"; see discussion } \\
\text { below) }{ }^{2} \text { and the angels who guard their } \\
\text { terrible storehouses. And the treasury of the } \\
\text { clouds, from which they come out and go } \\
\text { in. }\end{array}$ \\
\hline
\end{tabular}

\footnotetext{
${ }^{1}$ This is reflected in the presentation of the text in George Nickelsburg and James C. VanderKam, 1 Enoch 2: A Commentary on the Book of 1 Enoch Chapters 37-82 (Hermeneia. Minneapolis: Fortress Press, 2012), with chapter 42 lifted out and relocated to before this block of material. Their reconstruction of the text is also reflected in the separately published translation, George Nickelsburg and James C. VanderKam, 1 Enoch: The
} Hermeneia Translation (Minneapolis: Fortress Press, 2012).

2 Nickelsburg and VanderKam, 1 Enoch 2, 142.

${ }^{6}$ Translation from Francis I. Andersen, "2 (Slavonic Apocalypse of) Enoch: A New Translation and Introduction," in James H. Charlesworth, ed., The Old Testament Pseudepigrapha. Volume 1: Apocalyptic Literature and Testaments (New York: Doubleday, 1983), 112. 


\begin{tabular}{|c|c|}
\hline & $\begin{array}{l}\text { they carry the rain and the raindrops-all } \\
\text { this I investigated. } \\
\text { 40:10 I wrote down the treasuries of the } \\
\text { snow and the storehouses of the cold (or } \\
\text { "ice/frost", see discussion below) and the } \\
\text { frosty winds. I observed how, depending on } \\
\text { the season, their custodians fill up the } \\
\text { clouds with them, and their treasuries are } \\
\text { not emptied.7 }\end{array}$ \\
\hline $\begin{array}{l}5 \text { And I saw the storehouses of the sun and } \\
\text { the moon, from which they emerge and to } \\
\text { which they return, and their glorious return, } \\
\text { and how the one is more praiseworthy than } \\
\text { the other, and their splendid course. And } \\
\text { they do not leave the course, and they } \\
\text { neither extend nor diminish their course. } \\
\text { And they keep faith with one another } \\
\text { according to the oath that they have } \\
<\text { sworn }>\text {. }^{3}\end{array}$ & $\begin{array}{l}\text { Chapters } 11-16 \text { describe in detail the gates } \\
\text { of the sun and moon and the paths that they } \\
\text { follow. }\end{array}$ \\
\hline $\begin{array}{l}43: 1 \text { And I saw other lightnings and stars } \\
\text { of heaven; and I saw that he called them by } \\
\text { their names, and they listened to him. } 2 \\
\text { I saw a righteous balance, how they are } \\
\text { weighed according to their light, according } \\
\text { to the breadth of their spaces and the day of } \\
\text { their appearing. (I saw how) their revolution }\end{array}$ & $\begin{array}{l}40: 9 \text { And I wrote down the rumble of the } \\
\text { thunder and the lightening; and they showed } \\
\text { me the keys and their keepers, where they } \\
\text { go in and come out, by measure. They are } \\
\text { raised by means of a chain and they are } \\
\text { lowered by means of a chain, so that he } \\
\text { does not drop the clouds of anger with }\end{array}$ \\
\hline
\end{tabular}

\footnotetext{
${ }^{3}$ Nickelsburg and VanderKam, 1 Enoch 2, 142.

${ }^{7}$ Andersen, "2 (Slavonic Apocalypse of) Enoch," 166.
} 
produces lightning, and their revolution is according to the number of the angels, and they keep their faith with one another. ${ }^{4}$

60:11 And the other angel who went with me and showed me what is hidden told me what is first and last in heaven in the height and beneath the earth in the abyss, and at the ends of heaven and on the foundation of heaven, and in the storehouses of the winds, how the winds are divided and how they are weighed and how the springs of the wind are (divided and) numbered, according to the power of the wind and the power of the moon and according to the power of righteousness.

\section{Cf.:}

69:23 And there are preserved the voices of the thunder and the light of the lightnings. And there are preserved the storehouses of the hail and the storehouses of the hoarfrost, and the storehouses of the mist and the storehouses of the rain and the dew. ${ }^{5}$ terrible injuries and violence, and destroy everything upon the earth. ${ }^{8}$

40:11 I wrote down the sleeping chambers of the winds and I saw how their custodians carry scales and measures. At first they place them in the scales and secondly in the measure, and it is by measure that they release them skilfully into all the earth, lest the earth should be rocked by violent gusts. ${ }^{9}$

\footnotetext{
${ }^{4}$ Nickelsburg and VanderKam, 1 Enoch 2, 142.

${ }^{5}$ Nickelsburg and VanderKam, 1 Enoch 2, 304.

${ }^{8}$ Andersen, "2 (Slavonic Apocalypse of) Enoch, 166.

${ }^{9}$ Andersen, "2 (Slavonic Apocalypse of) Enoch," 166.
} 
Some comments need to be made in relation to the textual evidence for the two works, in order to prepare readers for some of the detail that will follow. The manuscript witnesses to the texts of both the Ethiopic and Slavonic books confront us with a range of variants. In the case of 2 Enoch, the variation is most strikingly seen in the existence of multiple recensions of varying length. ${ }^{10}$ These are often subsumed under two main categories: the longer and shorter recensions, though actually there are very long, very short and fragmentary versions of the book, as well. In his seminal English translation of the book, Francis Andersen elected to use the manuscripts $\mathrm{J}$ and $\mathrm{A}$ as exemplars of the longer and shorter recensions, respectively, an arrangement followed in Macaskill's edition of the Slavonic texts. ${ }^{11}$ The various recensions are also heavily affected by local dialect and by the emergence of distinct Slavic languages, so that multiple forms of words can occur, often distinguished by varying vowel lengths. Importantly, for all that such variations are encountered, the core detail that we seek to trace here is contained in all recensions: the variation is found at the level of the lexical detail and syntax of each manuscript. ${ }^{12}$ Where relevant in what follows, we will note and evaluate the points of divergence.

\section{a. Storehouses and Treasuries}

The Ge"ez of 1 Enoch 41:4 opens with a reference to Enoch's seeing the "storehouses"

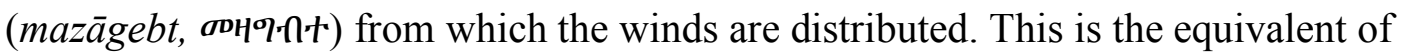
$\theta \eta \sigma \alpha u \rho o i ́$, used precisely with such significance in The Book of the Watchers (in 1 Enoch $17: 3$ and 18:1, to which we will return below); as such, it could legitimately be translated as

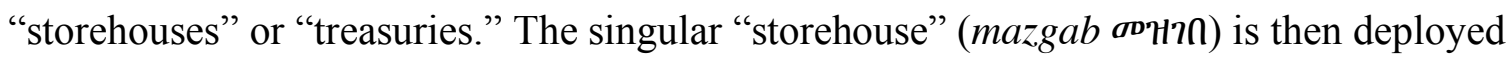
several times, associated in turn with hail, winds, mist and clouds. There are some minor variations between the manuscripts, with "the winds" omitted from several manuscripts (and

\footnotetext{
${ }^{10}$ For a full list of manuscripts and a discussion of the relationships between the recensions, see Grant Macaskill, The Slavonic Texts of 2 Enoch (Studia Judaeoslavica 6. Leiden: Brill, 2013), 13-35.

11 Translation, Nickelsburg and VanderKam, 1 Enoch 2, 142.

12 The most extensive differences between the recensions that is relevant to our argument here occurs in the material found in Chapters 11-16, where the longer recension contains a more elaborate description of the sun and moon, containing multiple details not found in the shorter recension. For present purposes, these are not relevant, but I will consider them in depth in a larger study that will follow this one.
} 
visibly deleted in EMML 2080), ${ }^{13}$ and "cloud(s)" encountered in both singular and plural, but generally the list of elements is consistently represented. The word translated as "hail" (barad, nce) is a straight equivalent to the Hebrew ברד, though it can also be used in Ethiopic for "hoarfrost." 14 It is found again, however, in 69:23, where it is paired with ashatzya (hinht? 9 ), which also (and more exclusively) means "hoarfrost." We should rightly see barad in both $41: 4$ and 69:23, then, to have its more common meaning of "hail." The term, "storehouses," meanwhile, is repeated again in 41:5, where it is used of the places in which the sun and the moon are kept. It is important to note that Enoch's vision of these is represented, in 41:3, as an event by which he learns cosmological secrets (hebu'ât, 'thth't), which are specified to include not only the secrets of the winds and the lightening/thunder, but also the secrets of the clouds and the dew. That last element is not mentioned in the subsequent description of the storehouses and their contents. ${ }^{15}$

Where the terminology about storehouses in the Ge'ez texts is consistent, the Slavonic terminology found in 2 Enoch 5:1-2 is subject to a degree of variation and, importantly, uses two different terms. The text of 5:1-2, in all of the manuscripts, repeatedly uses

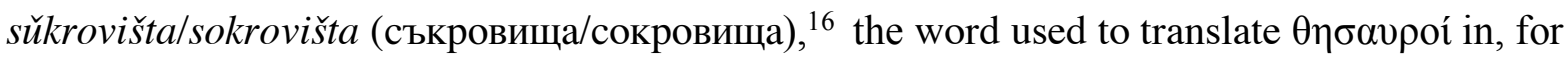
example, the Old Church Slavonic translations of Job 38:22. ${ }^{17}$ The manuscripts also

\footnotetext{
${ }^{13}$ Noted in Nickelsburg and VanderKam, 2 Enoch 2, 142.

${ }^{14}$ Wolf Leslau, Concise Dictionary of Ge 'ez (Wiesbaden: Harrassowitz Verlag, 2010), 98.

15 Jonathan Ben Dov has argued that the term "secrets" effectively functions as an equivalent term for storehouses or treasuries, as if they are used interchangeably. See his "Exegetical Notes on Cosmology in the Parables of Enoch," in Gabriele Boccaccini, ed., Enoch and the Messiah Son of Man: Revisiting the Book of Parables (Grand Rapids: Eerdmans, 2007). Ben Dov is undoubtedly correct that the two concepts have become closely associated, and, as will be seen from my interaction with this article in what follows, I find his analysis of the texts to be convincing. I am less convinced, however, that the terms have become interchangeable in the way that he suggests. The fact that, in 41:3, Enoch moves to his elaboration of the secrets about the distribution of the winds using "how" ('af, $\mathbf{k} G_{\text {. }}$ ), rather than "from which" indicates that the secrets in question are not principally understood to be places: he has learned how the winds are distributed principally, not where they are stored. Ben Dov's argument makes good sense of how this relates to the various biblical texts in which storehouses for the wind are noted, but makes less sense of the grammar of the verse itself.

${ }^{16}$ Illustrating the effects of dialect, $\mathrm{J}$ and $\mathrm{V}$ read скровища. $\mathrm{P}$ and $\mathrm{B}$ read сокровища. Other variants can be identified, but none has any significance for translation. See Macaskill, Slavonic Texts of 2 Enoch, 50-1.

17 Again, dialect effects result in this occurring as хранілица/хранилицА/хранилицоv. Macaskill, Slavonic Texts of 2 Enoch, 50-1.
} 
inconsistently use another word, khranilitsę/e/a (хранилицی/e/a), which designates a guarded place. In the longer recension, this word occurs in 5:1, in parallel with sǔkrovišta:

And there I perceived treasuries (s[ǔ $]$ krovišta) of snow and ice and angels who guard (drǔzhat, дръжат) their terrible storehouses (khranilitse). ${ }^{18}$

The manuscripts of the other recensions (i.e., short and very short) have the cognate verbal form khranęšta (хранаща, "they guard") in the place occupied by the noun khranilitsa in the longer texts, and repeat sǔkrovišta/sokrovišta as the object of the verb:

And they showed me there treasuries (sokrovišta) of the snow and cold, terrible angels guarding (khranešta) their treasuries (sokrovišta).

The shorter recension, meanwhile, does use the noun khranilitsa, but it does so at a different point. The noun occurs in combination with sǔkrovišta/sokrovišta in 5:2, which actually represents - as is often the case - a fuller version of the text than is found in the longer recension. ${ }^{19}$ The inconsistencies between manuscripts appear to reflect transmissional corruption or confusion of the cognate nominal and verbal forms, which are visually similar an easily misread in manuscripts that lack spaces between word.

Two important points can be made. First, the occurrence of nominal forms in both recensions (if at different points) suggests that both nouns were part of the original text. ${ }^{20}$ Second, and perhaps more importantly, it is significant that even at their points of variation, the two recensions are insistent on using a verb to indicate that angels "guard" the treasuries.

The meteorological elements listed in 2 Enoch 5:1-2 are snow, ice/frost and clouds. The manuscripts of the short recension have the word khladnaa (хладнаa "cold") for the second of these, but this is likely to be a corruption of the original reading: the manuscripts of the

\footnotetext{
${ }^{18}$ It also occurs in the chapter title found only in the manuscript $\mathrm{P}$ Because of the effect of dialect, it occurs in the title as хранилища. The inconsistency with the form found in the text itself reflects the secondary character of the chapter titles.

${ }^{19}$ First, the shorter recension, and its version includes both terms: khranilišta (because of the dialect, the term is here khranilitsa) and sǔkrovišta (again, because of dialect, the term is here sokrovišta)

20 The point is made by Andersen, “2 (Slavonic Apocalypse of) Enoch,” 112.
} 
longer recension $(\mathrm{J}, \mathrm{P}$, and $\mathrm{R})$ agree with those of the very short recension $(\mathrm{V}, \mathrm{N})^{21}$ - which are normally closer to the readings found in the short recension-and also with the reading in $\mathrm{B}$, an intermediate text type. All of these manuscripts read golotna (голотна) ${ }^{22}$. This word also occurs in the short recension texts, in a parallel pairing, at 40:10, which suggests that it has been altered here by scribal corruption. The discussion is important, because golotna can be translated as either ice or, more normally, frost. 2 Enoch 6 follows this with a description of the treasuries of the dew. As we have noted, "dew" is not listed in relation to a storehouse in the Ethiopic text, but it does occur in the immediate context, listed as one of the secrets that Enoch is given access to in his vision.

The subsequent mention of the storehouses and treasuries in 40:10 is doubly interesting. First, both of the words that we have seen to be used (khranilišta and sǔkrovišta) occur in the text, reinforcing the sense that they are used almost as poetic equivalents. Second, the khranilišta are specified to be of "the frost/ice and chill winds" (my translation). This point is masked somewhat in Andersen's generally reliable translation, which wrongly here renders golotnaa as "cold" rather than as "frost" or "ice." Once the point is recognised, we can see that, effectively, we have the same selection of elements found that we have seen in the Ethiopic.

For present purposes, I will pass over a detailed comparison of the sections of each book that speak of the sun and the moon and will simply offer some brief observations. First, the Ethiopic text continues its description of the storehouses seen by Enoch to include those in which the sun and moon are kept. There is no parallel to this concept in 2 Enoch, although much of the language used of the luminaries otherwise is quite similar. To make this point clearer: while both books contain discussions of the sun and the moon, and some similarities exist between these, only the Parables of Enoch includes these heavenly bodies in the schema of storehouses. In this, at least, 2 Enoch is closer to the Astronomical Book in its conceptuality, preferring to speak of gates through which the heavenly bodies pass. Second, it may be noteworthy that the inclusion of the resting places of sun and moon within the schema of the storehouses is not anticipated by the description of the secrets that Enoch is shown in 41:3.

\footnotetext{
${ }^{21}$ One manuscript of the very short recension, $\mathrm{B}^{2}$, is closer to $\mathrm{A}$ and $\mathrm{U}$ : it reads kholodna.

${ }^{22}$ Sometimes occurring as голотнаа/^.
} 


\section{b. Measures}

After the interruption of the vision of the cosmological secrets with the account of wisdom's descent and return to heaven, which some consider to reflect clumsy redaction, ${ }^{23}$ the Parables of Enoch returns in 43:1 to its description of the heavenly phenomena. The vision now recounts the secrets of the stars and lightening, perhaps linking them because they are considered to be made of the same stuff: the material of light. ${ }^{24}$ It is worth noting that classical thought was, at points, preoccupied with the nature of the substance of which stars were made, with this connected in certain strands of Greek philosophy to the concept of the stoicheia (elements) and, specifically, to that of pneuma. Both Engberg-Pedersen ${ }^{25}$ and Thiessen ${ }^{26}$ have recently argued that the association of stars with pneuma is a crucial element in the apostle Paul's thought, as he sees the fulfilment of the promise to Abraham - that his descendants would be like the stars - to be constituted by the presence of pneuma, the stuff of stars, in believers. The proximity of this to one of the occurrences of the title "Lord of

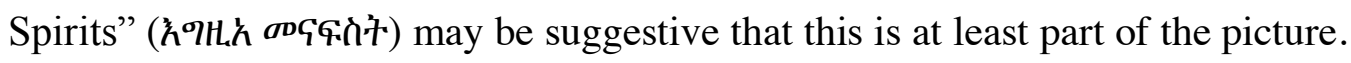

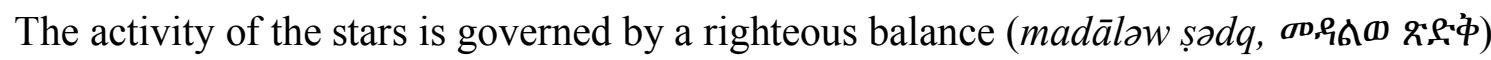
that Enoch sees. The Lord of Spirits calls the stars by name and they are weighed according to their light, size and the timing of their appearance. In broad thematic terms, this is linked to what we encounter in the Astronomical Book (1 Enoch 72-82), but this particular metrological device is not paralleled there.

It is important to note that this is not the first occurrence of a "balance" in the Parables of Enoch. The imagery also occurs in 41:1, where Enoch intimates that he saw "all the secrets of heaven, and how the kingdom is divided, and how human deeds are weighed in the balance." ${ }^{27}$ Standing, as it does, at the beginning of the account, this would suggest that the image of the balance has a certain controlling function over the Parable as a whole: Enoch

\footnotetext{
${ }^{23}$ See footnote 1 , above.

${ }^{24}$ Hence 1 Enoch 44: "some of the stars rise and become lightening, and they cannot abandon their form." Trans. Nickelsburg and VanderKam, 1 Enoch 2, 142.

25 Troels Engberg-Pedersen, Cosmology and Self in the Apostle Paul: The Material Spirit (Oxford: Oxford University Press, 2010)

${ }^{26}$ Matthew Thiessen, Paul and the Gentile Problem (Oxford: Oxford University Press, 2016).

${ }^{27}$ Nickelsburg and VanderKam, 1 Enoch 2, 136.
} 
will see how the Lord of Spirits will weigh both the heavenly spirits - the stars and the lightening - and the human ones. This makes sense of the association between the bodies of light and the spirits of righteous humans, which have been divided from the darkness by the Lord of Spirits (41:8-9); it also makes sense of the transition from the description of the stars/lightening and their weight to the naming of the righteous who dwell on earth (43:4).

Neither is this the last use of metrological imagery in relation to cosmology and meteorology in the Parables of Enoch. It occurs again in chapter 60:12-13, in a passage that draws upon much of the same imagery that we have seen already and that is followed by an extended description of the storehouses of the winds. An angel shows Enoch:

[what is] ${ }^{12}$ in the storehouses of the winds, how the winds are divided and how they are weighed, and how the springs of the winds are (divided and) numbered, according to the power of the wind, and the power of the light of the moon, and according to the power of righteousness. And the divisions of the stars, according to their names, and (how) all the divisions are made. ${ }^{13}$ And the thunders, according to the places where they fall, and all the divisions that are made among the lightnings, that they may flash, and their host, that they may obey at once. ${ }^{28}$

The dominant metrological imagery here is of dividing, rather than weighing, as such. Nevertheless, the process of division requires the winds to be weighed, and this is part of a process governed by the power of "righteousness." The detail that follows describes each distinctive wind (60:14-23) and the roles of the angels as they bring them out of their specific storehouses. The imagery of the balance is interwoven, then, with a detailed schema within which the concept of the storehouse/treasury plays a key structuring role, and within which the roles of angels in relation to the meteorological phenomena is a matter of interest.

2 Enoch does not parallel this perfectly, but it does associate the phenomena of thunder and lightning with some kind of measure/balance (měra, мłpa, 40:9). Here, the thunder and lightening are carefully weighed out and distributed by means of a chain, in order to protect the clouds and the earth. Once again, the image of the measure is part of a wider scheme here in the text. In 40:11, it is encountered again, with the angelic custodians who guard the chambers (lozhnitsa, ложница) of the winds using "scales and measures/balances,"29

\footnotetext{
${ }^{28}$ Nickelsburg and VanderKam, 1 Enoch 2, 224.

${ }^{29}$ Some of the manuscripts list only scales, привъсы, prives $\bar{y}$.
} 
ensuring that the winds are released in a controlled way, in order to avoid causing destruction to the earth.

Interestingly, this is followed by a description of Enoch's vision of those who have been judged and condemned (2 Enoch 40:13) which, in the manuscripts of the longer recension, is preceded by a brief description of Enoch's role as the one who has measured all things (2 Enoch 40:12). This is most likely to be a secondary addition at this point in the text, but it is one that reflects a theme found elsewhere in the book, that a key part of Enoch's role has been to measure the creation (see, esp., 43:1). ${ }^{30}$ Probably more important is the observation that the subsequent chapters develop a picture of the relative qualities of each time and each person $(43: 2)$ that leads to an account of their being weighed for judgement:

"On the day of the great judgement, every measure and every weight and every scale will be exposed as in the market, and each one will recognize his measure, and, according to measure, each shall receive his reward." (44:5, short recension). ${ }^{31}$

On one level, this is simply the stock imagery of justice and equity, ${ }^{32}$ but it is found here in the context of a developed scheme that links this justice, through the imagery of the righteous balance, to the cosmological equity that Enoch himself has measured. Sinners live in violation of the cosmic order that God has established, while the righteous live in line with it. Hence, while the details are different, the scheme is similar to that which we saw to be at work in the Parables of Enoch. Interestingly, much of the ethical material from this particular section of 2 Enoch is condensed into the medieval juridical/ethical tractate Merilo Pravednoe ("The Righteous Balance").

\footnotetext{
${ }^{30}$ On this point, see Andrei Orlov, 'The Origin of the Name 'Metatron' and the Text of 2 (Slavonic Apocalypse of) Enoch," in Journal for the Study of the Pseudepigrapha 11 (2000), 19-26. Orlov's case that the origin of the name Metatron might be explained by considering the Slavonic prometaya, an obscure term which occurs in Merilo Pravednoe, a juridical text based upon 2 Enoch, but which is generally corrupted in other manuscripts, is somewhat speculative. His analysis of the significance attached to Enoch's activity of measurement, however, and of the possibility that the Greek form metron might lie in the background of this obscure is helpful.

${ }^{31}$ Andersen, "2 (Slavonic Apocalypse of) Enoch," 173.

32 Joachim Schaper, "The Weight of Justice: Counting, Weighing, and Measuring in Ancient Israel's Social and Intellectual Worlds," forthcoming in Joachim Schaper and Grant Macaskill, eds., Congress Volume: The $23^{\text {rd }}$ Congress of the International Organisation for the Study of the Old Testament (Leiden: Brill, 2020).
} 


\section{c. The Imagery of Storehouses and Measures within the Primary Enoch Literature}

How does this overlapping imagery relate to the wider corpus of works that we label 1 Enoch? There are certainly some connections: in 17:3 and 18:1, part of the Book of the Watchers, Enoch sees storehouses/treasuries (mazāgebt) containing, respectively, the stars and the thunders, and the winds. In the case of the latter, there are some biblical source texts (notably, Psalm 135:7) that might influence the use of imagery. The concept of a storehouse or treasury in which the stars are kept is a distinctive development, however, although one that might be traced elsewhere in Second Temple literature, including that of the LXX. ${ }^{33}$ In a limited sense, then, the use of storehouse imagery in 17:3 and 18:1 might have contributed to its occurrence in the Parables and in 2 Enoch.

An interesting difference can be identified through careful comparison of the Parables of Enoch and 2 Enoch with the Book of the Watchers, however, and it is one that we will see to be mirrored in some of the other works that we will consider. Where the imagery of the storehouse or treasury is structurally significant in the Parables of Enoch and 2 Enoch - that is, it is an image that governs the structuring of the material, extended over a significant part of the work, within with the terms are repeated multiple times - in the Book of the Watchers it is effectively a detail, occurring in the context of a range of cosmological images, some of which are influenced by biblical terminology. The use of balance imagery, meanwhile, is a distinctive extension of the meteorological accounts of both The Parables of Enoch and Slavonic Enoch, in both of which, again, it has a structural rather than incidental significance, reflecting an integrated account of creational order and ethics. This is not paralleled by the other parts of 1 Enoch.

Building on the work of VanderKam, ${ }^{34}$ Jonathan Ben-Dov has recently observed the lack of literary dependence of The Parables of Enoch on the Astronomical Book: ${ }^{35}$ while both include cosmological material, and clearly belong within a broadly shared tradition, the description of the heavenly bodies in The Parables seems to present little, if any, evidence of influence by the language or concepts of the Astronomical Book. By contrast, Ben-Dov notes some more precise points of correspondence between The Parables and some rabbinic texts,

\footnotetext{
${ }^{33}$ See Ben-Dov "Exegetical Notes," 144-5.

${ }^{34}$ James C. VanderKam, "The Book of Parables within the Enoch Tradition,” in Boccaccinni, ed., Enoch and the Messiah Son of Man, 81-99.

35 Ben-Dov, "Exegetical Notes."
} 
which we will consider below. At the same time, and by way of contrast, he notes the apparent dependency of 2 Enoch on the calendrical scheme of the Astronomical Book, particularly in the lengthy description of the movements of sun and moon in 2 Enoch 11-16. This observation is sound, but Ben-Dov does not consider the extent to which The Parables of Enoch and 2 Enoch might distinctively relate to each other, on some of the very same points of terminology that he discusses. As we seek to analyse the origin and transmission history of these works, it is significant that the terminology and conceptuality of 2 Enoch suggests close entanglement with both the Astronomical Book and the Parables of Enoch, while those two works show little evidence of close entanglement with each other.

\section{Biblical Backgrounds}

There are some obvious biblical backgrounds to this material; these have clearly contributed some of the language encountered in the texts considered above and we will note their effects on other ancient texts in due course.

The language of the "good storehouse" (אוצרו הטוב) is found in Deuteronomy 28:12.

The LORD will open for you his rich (or "good") storehouse, the heavens, to give the rain of your land in its season and to bless all your undertakings (NRSV)

יפתח יהוה לך את אוצרו הטוב את השמים לתת מטר ארצך בעתו ולברך את כל מעשה ידך

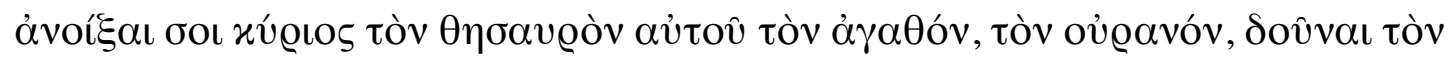

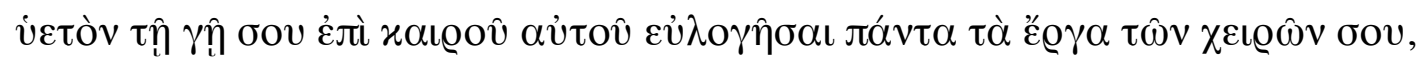

In bHagigah 12b, which we will consider below, this is used as the base text for the description of the sixth heaven, Makon, in which the storehouses of the terrible elements are found; the existence of such storehouses is represented as an inference from the specific form , "את אוצרו הטוב "the good storehouse," taken to imply that there must also be a storehouse of bad things. 
A more developed biblical description of such storehouses is found in Job 38:22. Here, the storehouses contain, specifically, the snow and the hail, but the text also speaks of other meteorological elements that parallel, to some extent, what we saw in the Enochic texts.

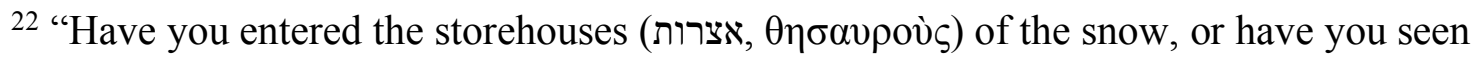
the storehouses of the hail,

${ }^{23}$ which I have reserved for the time of trouble, for the day of battle and war?

${ }^{24}$ What is the way to the place where the light is distributed, or where the east wind is scattered upon the earth?

25 "Who has cut a channel for the torrents of rain, and a way for the thunderbolt,

${ }^{26}$ to bring rain on a land where no one lives, on the desert, which is empty of human life,

${ }^{27}$ to satisfy the waste and desolate land, and to make the ground put forth grass?

28 "Has the rain a father, or who has begotten the drops of dew?

${ }^{29}$ From whose womb did the ice come forth, and who has given birth to the hoarfrost of heaven? (Job 38:22-29, NRSV).

It is, of course, of clear significance that the imagery of the storehouse or treasury in Job is used to contrast the limit of Job's knowledge and power with that of God, precisely by implying a negative answer. This is precisely the opposite of what we see in the Enochic texts, which are intended to show Enoch's privileged enjoyment of such knowledge, partly through their rhetorical contrast with Job 38:22. More importantly for our purposes, however, while a range of elements is listed, they are associated with a corresponding range of images associated with their locations: there is a "way" to where the light emerges, a "channel" through which the torrents pass; the text asks rhetorically whose "womb" the ice came from and whether the drops of dew were begotten by a father. The point of this observation is to note that the image of the storehouse is not a controlling device in Job 38, but rather an incidental detail, associated with just two of the elements (snow and hail). This contrasts with the Ethiopic and Slavonic Enoch material that we studied, where it is a developed concept by which the material is structured.

Something similar may be said about Jeremiah 10:13. Here, the true and exclusive creative and providential activity of God is described, in order to assert his uniqueness over the false gods (see Jeremiah 10:11-12, 14-16). 
${ }^{12}$ It is he who made the earth by his power, who established the world by his wisdom, and by his understanding stretched out the heavens.

${ }^{13}$ When he utters his voice, there is a tumult of waters in the heavens, and he makes the mist rise from the ends of the earth. He makes lightnings for the rain, and he brings out the wind from his storehouses. (Jer 10:12-13, NRSV)

That closing expression is also encountered in Psalm 135:7. In both texts, the image of the storehouse in which the winds are stored is simply one detail among several stock meteorological images, piled up in order to emphasize the creative and providential uniqueness of God. Psalm 33:7, likewise, uses the language of "storehouses," now

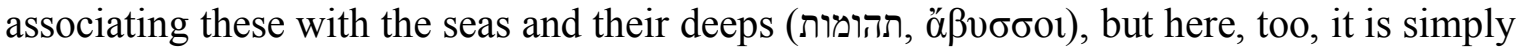
one of several cosmological details, brought together to describe the unique sovereignty of God in creation, exercised simply through the authority of his word. It is important to note that in Jeremiah 10:13, while the MT describes God bringing wind (רוח) from his storehouses, the LXX reads light ( $\varphi \tilde{\omega} \varsigma)$.

What, though, of the imagery of balance and measure? The language of the "righteous/just balance" is probably influenced by Job 31:6, where it is used of Job's hope that he will be judged fairly.

ישקלני במאזני צדק וידע אלוה תמתי

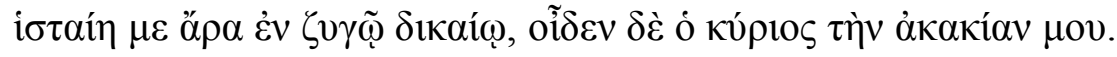

let me be weighed in a just balance, and let God know my integrity! (Job 31:6, NRSV)

As we have noted already, however, this is a well-established trope in ancient literature, a point explored in depth recently by Schaper. ${ }^{36}$ Hence, other biblical passages that employ the metrological imagery in relation to justice (e.g., Daniel 5:26-8) might be considered relevant, but not distinctively so. The suggestion that Daniel 5:26-8 might have distinctively influenced 1 Enoch 41:1, most recently made by Nickelsburg, ${ }^{37}$ is not without substance, but neither is it strictly necessary when the imagery was so common in relation to concepts of justice.

\footnotetext{
${ }^{36}$ Schaper, "The Weight of Justice."

${ }^{37}$ Nickelsburg and VanderKam, 1 Enoch 2, 137.
} 
The association of weight and measurement imagery with God's architectural activity in creation is also found in the biblical material, notably in Isaiah 40:12.

Who has measured the waters in the hollow of his hand and marked off the heavens with a span, enclosed the dust of the earth in a measure, and weighed the mountains in scales and the hills in a balance? (Is. 40:12, NRSV)

It is again noteworthy, however, that the image of the scales/balance used here is simply one of a range of measuring devices used by God in his role as architect or master-builder. The controlling image is that of construction, with the scales functioning as an incidental-if important - detail. It is specifically the mountains and hills that are measured in these devices; nothing is said about the substances of light, or of wind, or otherwise of climate. By contrast to the Parables of Enoch and 2 Enoch, where the imagery is used of ongoing or contemporary meteorological processes, Isaiah 42 uses the imagery of a historical event of construction.

Having surveyed the biblical texts, we can now make four general observations, by way of conclusion to this section, and in order to highlight the distinctions between the biblical and Enochic material. First, the imagery of "storehouses" in the biblical material itself is exclusively used of meteorological elements or of the sea. As Ben-Dov has noted, it is not used of light or of the heavenly luminaries, apart from in LXX translations. ${ }^{38}$ Second, where the imagery of "storehouses/treasuries" is used, it is part of a wider range of images intended to highlight the uniqueness of God in distinction to the false gods; it is not, itself, the controlling image in a scheme. Third, God's providential activity is associated very directly with the elements stored in these places: there are no intermediary beings, such as angels, mentioned in the accounts, since the concern is to emphasize God's distinctive sovereignty. Fourth, where the imagery of "measure" or "scales" is used, it is likewise part of a wider scheme, to which it merely contributes one detail, which is defined by the depiction of God as a master builder, directly involved in the construction of the cosmos.

\section{Parallels in the Dead Sea Scrolls}

\footnotetext{
${ }^{38}$ See Ben-Dov “Exegetical Notes,” 144-5.
} 
A number of the Qumran texts contain the language of the storehouse or treasury, associated with the meteorological elements. 11Q14 Fr. 2 Col ii, 8, for example (paralleled by 4Q285, fragment 1) refers to God opening his good storehouse and sending down blessing, in the form of rain and dew, elaborated as "early" and "late" rains. This is clearly an expansion of Deuteronomy 28:13, since the specific expression אוצרו הטוב is used, with storehouse remaining in the singular. The storehouse/treasury image is also found in the Rule of the Community, in 1QS X, 2.

${ }^{1}$ at the times ordained of God: when light begins its dominion — each time it returnsand when, as ordained, it is regathered into its dwelling place;

${ }^{2}$ when night begins its watches - as He opens His storehouse and spreads darkness over the earth — and when it cycles back, withdrawing before the light;

${ }^{3}$ when the luminaries show forth from their holy habitation, and when they are regathered into their glorious abode; when the times appointed for new moons arrive $\mathrm{e}^{39}$

The association of darkness with a storehouse may well reflect the influence of Isaiah 45:3. This is interesting, as Ben-Dov has seen this verse to have been particularly influential on the combination of the language of "secrets" and "storehouses in" in the Parables of Enoch. ${ }^{40}$ More interesting, however, is the fact that while the word "storehouse/treasury" occurs only once, and might therefore be seen as just one image among several, the other images that are used are also of places of residence: the light has a "dwelling place" (מעון) and the luminaries have a "holy habitation" (זבל קדש). These nouns are found in biblical texts that describe God's own place of residence in the heavens, ${ }^{41}$ and they are also among the technical names for the specific heavens in b.Hagigah $12 \mathrm{~b}$, which we will consider below. There is nothing to suggest that the terms are used here with the same significance that they have in the latter text — the details associated with them are entirely different — but it is noteworthy that they

\footnotetext{
39 Translation Michael Wise, Martin Abegg and Edward Cook, “Serek le'anshey ha-Yahad,” in D.W. Parry, and

E. Tov, eds., Dead Sea Scrolls Reader. Part 1, Texts Concerned with Religious Law (Leiden: Brill, 2003$), 37$.

${ }^{40}$ Ben-Dov, "Exegetical Notes," 147. See, however, my comments above, in footnote 14.

${ }^{41}$ For מעון see Deut 26:5, Jer 25:30, Psalm 68:5. For זבל See Isaiah 63:15.
} 
function here within an extended description of places of containment or residence, which plays a structuring role within the text.

We also find the imagery of the scales/balance being used within the Scrolls, with a form similar to the one that we saw to be used in the Parables of Enoch and 2 Enoch: the scales/balance of justice. The expression occurs in 4QInstruction, in 4Q418 fragment 126, column II, 3-4:

$[\ldots \mathrm{n}]$ ot one of all their host ever rests ...

And y[ou, understandi $]$ ng one, truthfully measure all resources of men ... for with an eph[a]h of truth and a measure of righteousness (משקל צדק) God apportions all [their] $\mathrm{d}[$ eeds ...]

He has spread them out, in truth he has established them and by all who delight in them [they] are studied. ${ }^{42}$

This is not the only occurrence of the image, ${ }^{43}$ but it is a particularly significant one. The language of the "measure of righteousness" is used in close proximity to a description of the unresting "host," which is probably a reference to the stars and their movements. The specific word for measure here, משקל, is not the same one used in conjunction with צדק in Job 31:6 (מאזנים); it is more obviously a functional parallel to the term ephah. Furthermore, the construction with צדק here appears to be genitival, rather than adjectival. Broadly, though, we seem to encounter here something similar to what we saw in our Enochic texts, that is, an image of God's righteous dealings with human beings linked to his ordering of the heavenly bodies through metrological imagery. What is distinctively interesting about these occurrences is that they fit within a broader schema of God's regulative justice and the illumination of the addressees of the work to be able to live according to it and, indeed, to be righteous in their own judgments. That is, the imagery is not simply one detail within the account, but has a more programmatic significance. ${ }^{44}$ Furthermore, it is closely linked in

\footnotetext{
${ }^{42}$ Translation, Matthew J. Goff, 4QInstruction, (Atlanta: Society of Biblical Literature Press, 2013), 274.

${ }^{43}$ See also fragment 1276.

${ }^{44}$ For the programmatic significance of the raz nihyeh within 4 QInstruction, and its relationship to cosmic order, see Macaskill, Revealed Wisdom and Inaugurated Eschatology in Ancient Judaism and Early Christianity (Leiden: Brill, 2007), 72-114, and Goff, 4QInstruction, 19-23.
} 
4QInstruction to the core concept of revealed wisdom, the raz nihyeh. Earlier in column II, partially preserved in fragment 123 , the expression is used immediately before a reference to the weighing of deeds, and shortly after a reference to the entrance of the years and the departure of the periods.

Any parallels with the Enochic material are of a broad kind, however, and are a matter of the proximity of certain concepts (i.e., the measure and the order of the heavenly bodies) rather than the kind of direct linkage that we saw in those texts. Moreover, there is no evidence of the specific combination of details that we saw there, where the balance/measure language is used as part of a pattern with the language of the storehouse or treasury.

\section{A Rabbinic Parallel in bHagigah $12 \mathrm{~b}$}

As noted already, bḤagigah $12 \mathrm{~b}$ also develops the imagery of the storehouses, referencing Deuteronomy 28:12 along the way.

Makon is that in which there are store(house)s ${ }^{45}$ of snow (אוצרות שלג) and store(house)s of hail (ואוצרות ברד), and the loft of harmful dews (עליית טללים רעים), and the loft of raindrops (עליית אגלים), the chamber of the whirlwind and storm (וחדרה של סופה וסערה), cave of vapour (ומערה של קיטור), and their doors are of fire, for it is said: The Lord will open unto thee His good storehouse, ${ }^{47}$ the heavens" (Deuteronomy 28:12), which indicates the existence of a storehouse that contains the opposite of good. ${ }^{48}$

The elements here are somewhat similar to those encountered in the Ethiopic and Slavonic material (snow, hail, dew, mist), and while the language of "storehouses" (אוצרות) does not occur exclusively, but alongside the parallel terms "loft" (עליה), "chamber" (חדר) and "cave" (מערה), there is clearly a structuring concern to discuss the places where the elements are

\footnotetext{
${ }^{45}$ I have amended the translation, which uses the word "stores" for the sake of terminological consistency.

46 is omitted by R. Elijah of Wilna.

${ }^{47}$ I have, again, amended the translation (which uses "treasure," rather than "storehouse" to translate אוצר here).

48 Translation, Isidore Epstein, The Babylonian Talmud: Seder Mo'ed (London: Soncino Press, 1938).
} 
stored. This is different to what we saw in the biblical material, where the mention of such places is merely one detail among many. It is noteworthy, however, that what are listed as kept in these storehouses are exclusively bad and harmful things, used for the punitive purposes that are detailed in the wider text of Deuteronomy 28. This triggers a question in the Gemara as to whether such things are in heaven or are on the earth. The text draws upon Psalm 148:7 (which lists meteorological elements, but without any mention of storehouses) and Psalm 5:5 (which indicates that evil cannot sojourn with God) as it debates whether the evil things can reside in heaven or must be stored somewhere on earth.

While similar to the Enochic material in certain regards, then, the Bavli passage differs from it in its distinctively negative description of the storehouses. It also, at this point, shows no interest in associating the storehouses with particular angels and their activity; while the priestly activity of Michael is mentioned earlier in the chapter, taking place in Zevul, and a group of ministering angels is described as reciting songs by night, in $\mathrm{Ma}$ 'on, there is no description of such beings being involved in God's providential operations in relation to the weather, which are associated only with him.

\section{Parallels in 3 Enoch}

Several points in the text of 3 Enoch parallel more closely what we find in the Ethiopic and Slavonic material, though still not perfectly. Enoch himself, as Metatron, is put in charge of all the heavenly treasuries and storehouses (10:6 and 48c:3); ${ }^{49}$ it is not specified at either point that these contain the meteorological elements, though elsewhere in the vision $(37: 2)$ Enoch speaks of treasuries of lightening and storehouses of storms, arranged in circles that are positioned relative to other circles containing meteorological phenomena (hurricane blasts and winds):

between one tongue and another is a circle of treasuries of lightning (אוצרי ברקים); behind the treasuries of lightning is a circle of hurricane blasts; behind the hurricane blasts is a

\footnotetext{
${ }^{49}$ See Philip Alexander, "3 (Hebrew Apocalypse of) Enoch," in James H. Charlesworth, ed., The Old Testament Pseudepigrapha. Volume 1: Apocalyptic Literature and Testaments (New York: Doubleday, 1983), 264, 311.
} 
circle of storehouses of storm (גנזי סערה); behind the storehouses of storm is a circle of winds, thunderclaps, thunders, and sparks; behind the sparks is a circle of tremors. ${ }^{50}$

It is interesting that the text does not simply repeat the biblical term אוצר, but now also uses גנז. This is somewhat similar to what we saw in the Slavonic material, where two words are used with equivalent force. Similarly, the association of these terms with Enoch's learning of the heavenly and creational secrets (see, especially 3 Enoch 11 and 48c) parallels what we see in the Parables and 2 Enoch.

In certain regards, however, the material in 3 Enoch is much more radically developed than what we saw in the Parables of Enoch and in 2 Enoch. Like these books, 3 Enoch is interested in the involvement of the angels in the oversight of the storehouses and the management of the meteorological processes. Here, however, that interest has developed to the point where each of the angels is named in relation to their area of responsibility:

Gabriel the angel of fire

Baradi'el, the angel of hail;

Ruhi'el, who is in charge of wind;

Baraqi'el, who is in charge of lightning;

Et cetera ... ${ }^{51}$

This would appear to reflect a much more developed angelological scheme than that seen in the Parables and in 2 Enoch. Even this interest, however, is made to serve the developed account of the awesomeness of the divine throne and the elevated status of Enoch. The angels named in chapter 14 react fearfully to Enoch, as Metatron, who becomes the keyholder and manager of the various stores, thus taking the role played by the angels themselves in the Parables and in 2 Enoch. The text, moreover, seems much more concerned to indicate his detailed and exclusive knowledge of the content of the storehouses than to explain the regulation of the weather. So, for example, in $22 \mathrm{~b}$ :

${ }^{3}$ How many bridges are there? How many rivers of fire? How many rivers of hail?

\footnotetext{
${ }^{50}$ Alexander, "3 (Hebrew Apocalypse of) Enoch,” 290.

${ }^{51}$ Alexander, 3 (Hebrew Apocalypse of) Enoch,” 267.
} 
${ }^{4}$ How many treasuries of snow? How many wheels of fire? .How many ministering angels? There are 12,000 myriads of bridges, six above and six below; 12,000 myriads of rivers of fire, six above and six below; 12,000 treasuries of snow, six above and six below; 24,000 myriads of wheels of fire, twelve above and twelve below, surrounding the bridges, the rivers of fire, the rivers of hail, the treasuries of snow, and the ministering angels

Interestingly, too, the lengthy passage that describes the winds ( 3 Enoch 23$)^{52}$ does not make use of the metrological imagery that we saw to be significant in the Parables; rather, it brings together an array of biblical texts that speak of the winds and combines their imagery. In fact, there is only one point in 3 Enoch where scales/balance imagery is used, in 18:20.

Why is his name called Šoqedhozi? Because he weighs men's merits in scales in the presence of the Holy One, blessed be he. ${ }^{53}$

So, while there appears to be more entanglement with the content of Parables of Enoch and 2 Enoch than is seen in the biblical material or even in b.Hagigah, then, there are also some telling differences. 3 Enoch appears to be radically more developed in its angelological scheme and in its concern with the distinctive status of Enoch. It also shows less interest in the meteorological processes themselves, which occur only in relation to these schematic concerns.

\section{Parallels in other Pseudepigrapha}

When we turn to consider other pseudepigraphical texts, many of which are of uncertain dating and provenance, we find a number of rather general similarities that are, nevertheless, important to catalogue, as well as some more suggestive points of parallel.

In 2 Baruch, which has come to us in Syriac, there is a brief mention of the "treasuries of the light," listed among the range of secrets revealed to Moses by God:

\footnotetext{
52 Alexander, 3 (Hebrew Apocalypse of) Enoch," 307-8.

${ }^{53}$ Alexander, 3 (Hebrew Apocalypse of) Enoch," 273.
} 
...the multitude of the angels which cannot be counted, the powers of the flame, the splendor of lightnings, the voice of the thunders, the orders of the archangels, the treasuries of the light, the changes of the times ...

It is perhaps noteworthy that the listing of this treasury occurs directly after that of "the orders of the archangels," and immediately before "the changes of the times." Although the possible connection of these within the kind of schema that we saw in the Enochic texts is not developed, it is suggestive of an original context in which these things were associated with each other, or within which traditions existed that linked specific angels to the treasuries of light and to their operation within the calendar. Elsewhere in the book, we find the traditional biblical imagery of treasuries for the rain (10:11) and also the image of a treasury containing righteous deeds for the godly.

4 Ezra also contains a reference to "treasuries of light," (6:40), contained in an expanded description of the divine command in Genesis 3. This reflects a wider concern within that book to assert God's sovereignty over creation, and hence the demands of monotheism. Importantly, while this reference contributes to the growing postbiblical tradition of treasuries that contain light, it has no programmatic or structural significance. Another interesting parallel to the Enochic material is found in 5:37, which speaks of the "closed chambers" in which the winds are stored; the expression is similar to the one found in Parables of Enoch 41:3.

Testament of Levi 3:2 is often noted as a parallel text to those in the Enochic corpus that speak of storehouses for the elements. While neither "storehouse" nor "treasury" is used, the text describes the heavens that Levi has seen, the lowest of which "contains fire, snow, and ice, ready for the day determined by God's righteous judgment." One striking feature of this text (which is not paralleled in the Aramaic Levi Document) is that these elements are represented as substances of punishment. The parallel with the Enoch texts, which are interested in the elements as they contribute to meteorological phenomena and not only as they function in the eschatological judgement, is actually quite limited. If anything, there is a closer parallel to bHagigah $12 \mathrm{~b}$, although this is also limited, since the elements listed do not entirely correspond.

A limited correspondence can also be noted in Pseudo-Philo 32:7, and its description of God's appearing at Sinai (Exodus 19\&20). 
And then when the world's foundation was moved, the heavenly hosts speeded the lightnings on their courses, and the winds brought forth noise from their chambers, and the earth was shaken from its firmament, and the mountains and cliffs trembled in their joints, and the clouds lifted up their floods against the flame of fire so that it would not burn up the world. ${ }^{54}$

The text is of particular interest because it combines the traditional biblical concept of storehouses (here, "chambers") for the wind with a particular way of describing the lightning as being governed by the heavenly hosts. Whether the hosts in question are angels or stars, the description moves beyond the biblical description in Exodus 19:16/20:18, in ways that seem to assume an involvement of the heavenly hosts with the activity of lightning.

Finally, and most interestingly, we note a set of correspondences with a prayer recounted in the Apostolic Constitutions 8.12.6-27. The similarities of several prayers in this text with Jewish synagogue prayers have long been recognised. ${ }^{55}$ These verses are, indeed, categorised in the Charlesworth Old Testament Pseudepigrapha as a Hellenistic Synagogal Prayer, albeit one now containing many Christian interpolations. Whether the work is indeed of Jewish origin - and the methodological issues around such identifications in that volume are notorious - the parallel with The Parables of Enoch and 2 Enoch is interesting.

For you are the one ... who brought light out of the treasuries, and at the contraction of this (light), the one who brought the darkness for rest for the living creatures moving about in the world; 56

On one level, this may simply add to the body of texts that we have noted to use the language of "treasuries" in relation to the storage of light. The wider context, however, contains some further suggestive similarities:

\footnotetext{
54 Translation, Daniel J. Harrington, "Pseudo-Philo: A New Translation and Introduction," in James H. Charlesworth, The Old Testament Pseudepigrapha. Volume 2: Expansions of the "Old Testament" and Legends, Wisdom and Philosophical Literature, Prayers, Psalms, and Odes, Fragments of Lost JudeoHellenistic Works (New York: Doubleday, 1985), 346.

${ }^{55}$ For a full discussion, and strong arguments in favour of seeing the text as drawing upon Jewish prayers, see David Fiensy, "Redaction History and the Apostolic Constitutions," Jewish Quarterly Review 72 (1982), 293302.

56 Translation, D.R. Darnell, "Hellenistic Synagogal Prayers,” in Charlesworth, OTP 2, 691.
} 
For you filled your world, and divided and arranged it ...

with cycles of years.

with numbers of months and days;

with arrangements of customs;

with courses of rain-producing clouds, for the generation of fruits, and the

care of living creatures;

(and with) a balance of winds,

blowing when they are ordered by you. (Apos. Con. 8.12.15). ${ }^{57}$

The language here is suggestive of the interest in the cycles of the luminaries that is seen in the Enochic material. This, of course, is hardly a parallel specific to the Parables or 2 Enoch, and there is inadequate detail to see this as having any kind of polemical force that would be indicative of specific calendrical commitments. The fact that it is closely followed by a reference to the "balance" of the winds, though, is interesting. It is not identical to the metrological imagery used in the Parables and in 2 Enoch, but does represent something that we have really only seen to be found in those works: the use of metrological imagery in relation to meteorological processes.

Although it is not part of the substance of our concern here, we might also note that there are some interesting similarities in subsequent account of the creation of man (Apos. Con. $8.12: 16-17)$ to the one found in the longer recension of 2 Enoch. Both represent man as a microcosm and both associate him distinctively with God's Wisdom. ${ }^{58}$ This, of course, is a widely found idea in ancient Christian literature and a prominent element in Patristic thought, but the fact that it coincides so closely with the imagery discussed above suggests that a more extensive comparison of these texts with the Apostolic Constitutions, tracing other points of common detail, would be beneficial.

\section{Concluding Synthesis}

\footnotetext{
57 Translation, D.R. Darnell, "Hellenistic Synagogal Prayers," in Charlesworth, OTP 2, 691-2.

${ }^{58}$ For an extended discussion of this, see Christfried Böttrich, Adam als Mikrokosmos: Eine Untersuchung zum slavischen Henochbuch (Frankfurt: Peter Lang, 1995).
} 
In this final section, then, we turn to an evaluation of the evidence that has been considered throughout, offering a set of conclusions and some suggestions.

First, the Parables of Enoch and 2 Enoch are distinctive in their development of an extended scheme within which the imagery of the storehouse functions as the governing device within accounts of meteorology. While the imagery is widely found in the biblical material and in postbiblical texts, these texts are distinctive in developing it in an extended way, with the imagery of the storehouse and/or treasury governing the account. Most texts use the storehouse/treasury image as part of a wider range of images associated with the meteorological elements or, in the postbiblical literature, with light and luminaries. Even those texts that do contain more extended accounts of the places in which the meteorological elements or luminaries are contained, such as the Rule of the Community, do not use the storehouse as the principal image, but include it within a wider list of heavenly places. The closest parallels are found in bHagigah $12 \mathrm{~b}$ and 3 Enoch 37, which is undoubtedly significant, but both are marked by a number of differences. In the case of bHagigah $12 \mathrm{~b}$, the storehouses are associated with elements reserved for eschatological punishment - there is no interest in meteorology, as such - and in the case of 3 Enoch 37, the real interest is in the divine throne. 3 Enoch 48, which refers in a broader way to the storehouses, is also uninterested in meteorology itself; it is more clearly driven by a concern to show Metatron's position of delegated authority over the angels.

Second, both the Parables of Enoch and 2 Enoch use the imagery of the balance/scales in relation to meteorological phenomena, with this use of the imagery structurally interwoven with its traditional deployment in relation to justice and judgement. A limited parallel to this can be traced in the use of measure-imagery in 4QInstruction, which also links creational ordering and providence to God's judgement and the moral life of those to whom the raz nihyeh has been revealed. 4QInstruction, however, does not contain anything that corresponds to the image of a meteorological balance. Apostolic Constitutions 8.12.6-27 is the one other text that includes such a picture and that develops it in conjunction with the imagery of the storehouse. Its correspondence with Parables of Enoch and 2 Enoch is far from perfect: the elements associated with both the balance and the storehouse are different in the three texts. Nevertheless, the similar pattern of combination must be considered significant, and that significance would grow if the other points of similarity noted above are sustained through more careful and extensive comparative work.

Third, both the Parables of Enoch and 2 Enoch link the imagery of the storehouses and that of the balance to the activity of angelic figures who are responsible for the oversight and 
management of the meteorological elements. This sets these works apart from the biblical texts, which represent the management of the elements as something done by God himself. A similar interest in the angelic custodians is seen in 3 Enoch, but the imagery in that text appears to reflect a much more developed account, with the angels responsible for each element named. In addition, 3 Enoch systematically shifts the roles of management and oversight onto Enoch himself, as Metatron. This suggests that while there are, indeed, close connections between 3 Enoch and both the Parables of Enoch and 2 Enoch, 3 Enoch represents a more evolved text. The Syriac Baruch, meanwhile, might represent a fairly broad paralleling of this cluster of associations, though not one that appears to require any kind of literary dependency.

Fourth, even between the Parables of Enoch and 2 Enoch, the parallels are close, but are not of a kind that suggest direct literary dependency of one work upon the other. The distribution of the language and imagery is different in the two works, and although there are quite striking similarities, the correspondence is not of a word-for-word kind, even allowing for the kinds of changes that might have been introduced through translation into different language families. Rather, the similarities are of a kind that suggest a particular entanglement of traditions, within which certain tropes had a measure of popularity. We might note, however, that this traditional relationship still appears to be closer than that which VanderKam considers to exist between the Parables of Enoch and the Astronomical Book. That is, within a broader common tradition of heavenly ascent and the revealing of cosmological secrets, the Parables of Enoch and 2 Enoch appear to be connected within a closer sub-tradition. Differently from the Parables, 2 Enoch does contain a calendrical schema that appears to be somewhat dependent on the one found in the Astronomical Book, but the key word here is "somewhat": the schema is notoriously messy in the manuscripts and is undoubtedly hybridised with other traditions about the heavenly bodies drawn from outside of Judaism. We should be careful, then, of using the calendrical imagery in 2 Enoch to suggest a closer relationship to the Astronomical Book than to the Parables. Nevertheless, we can begin to see how our study of this imagery allows us to engage in some "triangulation" of the Parables of Enoch, 2 Enoch, and the primary Enochic literature to which we have witnesses among the Qumran finds.

This brings me, finally, to a suggestion concerning the origin or transmission history of the two works now preserved exclusively in Ethiopic and Slavonic, respectively. The similarity that we have noted between the sub-tradition that they appear to represent and the Apostolic Constitutions is particularly interesting because the latter work is widely believed 
to have originated in Syria. ${ }^{59}$ There might be a number of explanations for the similarity, but it is not the only potential link to Syria that might need to be factored into the discussion. We have also noticed, of course, the broad parallel in the Syriac Apocalypse of Baruch. More importantly, the Parables of Enoch has a demonstrably close connection to some of the imagery in Matthew's Gospel, which is widely held to have been composed in Syrian Antioch; most notable of these is the representation of the Son of Man seated on the throne of his glory. ${ }^{60}$ There are also some similarities between the extended use of the beatitude form in Matthew's Gospel and in 2 Enoch. Once these observations are brought together, they suggest that Syria may be an important part of the picture.

Clearly, more needs to be done to evaluate this possibility - all that we have done here is to identify a small number of limited parallels — but it may have powerful explanatory value in relation to the origin or transmission history of the works in question, the traditions that they may have channelled, or the traces they may have left. The mutual influence of Christian and Jewish traditions in the area is well known and the role played by the Syrian church in shaping the wider culture of the Greek-speaking early Christian world is significant. To this point, the question of how a Syrian context of origin or transmission may have affected the traditions preserved in the Parables of Enoch or 2 Enoch has not yet received much attention. Our suggestion is that a more detailed comparison of these two texts with works of Syrian provenance might highlight other points of contact and open new pathways for reflection on the origin and development of these challenging works.

\footnotetext{
${ }^{59}$ See Fiensy, "Redaction History and the Apostolic Constitutions," 293. See also G. Rouwhorst, "Jewish Liturgical Traditions in Early Syriac Christianity," Vigiliae Christianae 51 (1997), 72-93.

${ }^{60}$ See Grant Macaskill, "Matthew and the Parables of Enoch,” in Darrell L. Bock and James H. Charlesworth, Parables of Enoch: A Paradigm Shift (London: Bloomsbury T\&T Clark, 2013), 218-30.
} 